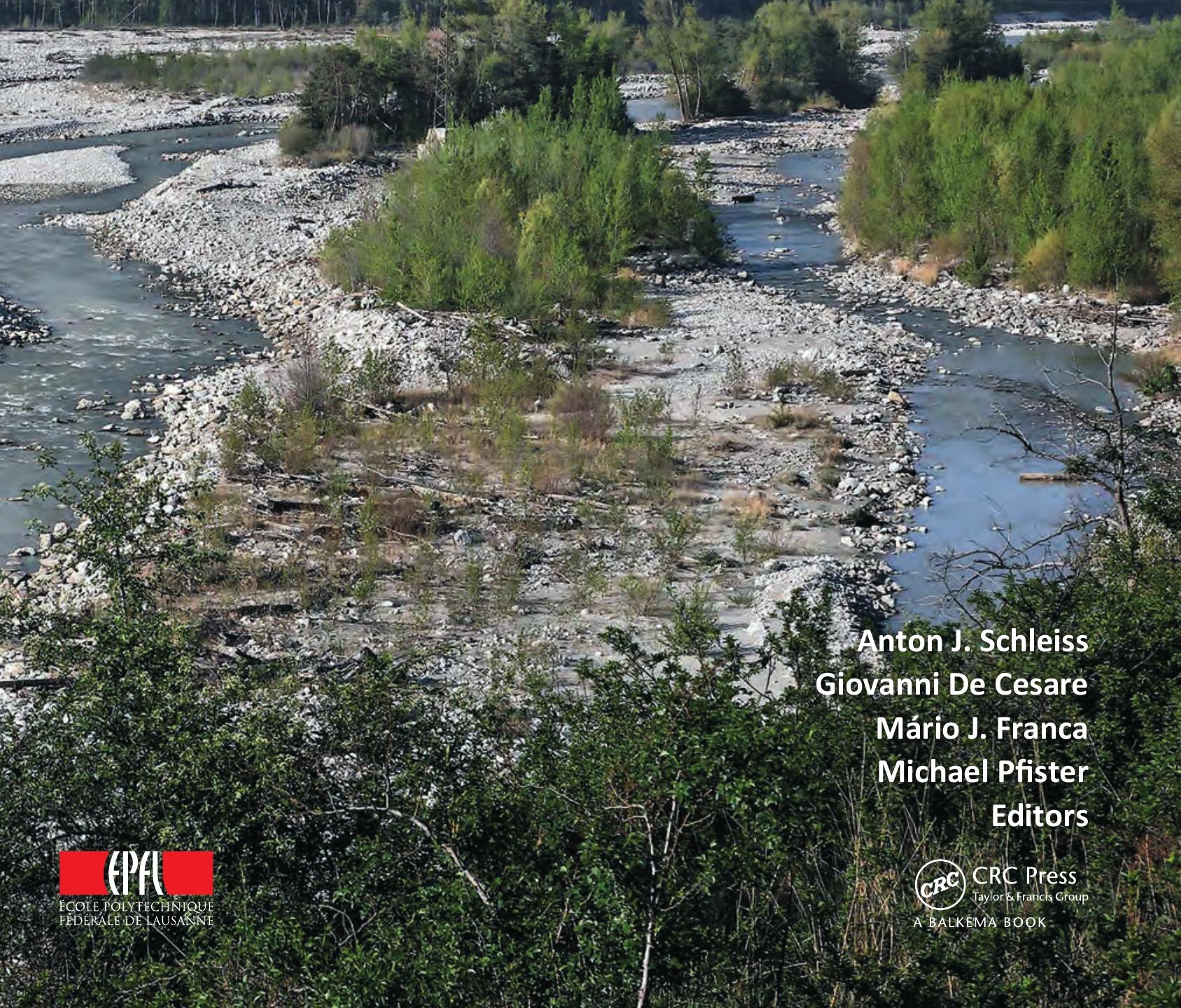


RIVER FLOW 2014 
This page intentionally left blank 
PROCEEDINGS OF THE INTERNATIONAL CONFERENCE ON FLUVIAL HYDRAULICS (RIVER FLOW 2014), LAUSANNE, SWITZERLAND, 3-5 SEPTEMBER 2014

\section{River Flow 2014}

\section{Editors}

Anton J. Schleiss, Giovanni De Cesare,

Mário J. Franca \& Michael Pfister

Laboratoire de Constructions Hydrauliques ( $L C H$ )

École Polytechnique Fédérale de Lausanne (EPFL), Switzerland 
Cover photo: Rhone River near Sierre (VS), Switzerland. Courtesy: Tony Arborino

CRC Press/Balkema is an imprint of the Taylor \& Francis Group, an informa business

(C) 2014 Taylor \& Francis Group, London, UK

Typeset by V Publishing Solutions Pvt Ltd., Chennai, India

Printed and bound in Great Britain by CPI Group (UK) Ltd, Croydon, CR0 4YY

All rights reserved. No part of this publication or the information contained herein may be reproduced, stored in a retrieval system, or transmitted in any form or by any means, electronic, mechanical, by photocopying, recording or otherwise, without written prior permission from the publisher.

Although all care is taken to ensure integrity and the quality of this publication and the information herein, no responsibility is assumed by the publishers nor the author for any damage to the property or persons as a result of operation or use of this publication and/or the information contained herein.

Published by: CRC Press/Balkema

P.O. Box 11320, 2301 EH Leiden, The Netherlands

e-mail: Pub.NL@taylorandfrancis.com

www.crcpress.com - www.taylorandfrancis.com

ISBN: 978-1-138-02674-2 (Hbk + USB-card)

ISBN: 978-1-4987-0442-7 (eBook PDF) 


\section{Table of contents}

Preface $\quad$ xxiii

Acknowledgements $\quad$ xxv

Organization $\quad$ xxvii

Sponsors $\quad$ xxix

\section{Keynote lectures}

River networks as ecological corridors for species, populations and pathogens of water-borne disease

A. Rinaldo

River turbulence: Current state, challenges, and prospects

V. Nikora

Climate and human forcing of Alpine river flow

S.N. Lane, M. Bakker, D. Balin, B. Lovis \& B. Regamey

A sediment journey through the Bermejo River of Argentina and Bolivia: From debris flows to meandering, ending in washload

M.H. Garcia

\section{A River hydrodynamics}

\section{A.1 Turbulent open-channel flow and transport phenomena}

Measurement of mass exchange between a main flow and an adjacent lateral cavity

W. Cai, M. Brosset, E. Mignot \& N. Riviere

Entrainment mechanisms in river embayments

Y. Akutina, S.J. Gaskin \& L.B. Mydlarski

Three-dimensional turbulent structure and spatial distribution of tractive force in open channel flow with side-overflow

N. Yamashita \& T. Ohmoto

Streamwise vorticity generation in a compound meandering channel

I. Mera, J. Anta \& E. Peña

Experiments on two consecutive open channel bends

A. Farhadi, M. Tritthart, M. Glas \& H. Habersack

A.M. Ricardo, S. Di Carlo, M.J. Franca, A.J. Schleiss, P.M. Sanches \& R. M.L. Ferreira

M. Sanjou, T. Okamoto, Y. Tanaka \& K. Toda

Transition from permeable to impermeable beds and vice versa in open channels:

Effects on the velocity distribution of turbulent flow

G. Pechlivanidis, E. Keramaris \& I. Pechlivanidis 
Laboratory experiments and shallow water simulations of gravity currents moving on flat and up-sloping beds

C. Adduce, V. Lombardi, G. Sciortino, M. La Rocca \& M. Morganti

Investigation of the turbulent boundary layer and associated energy dissipation

in an open channel flow behind a series of regular grids

T.A. Earl, S. Cochard, L. Thomas \& L. David

Effect of spatial average on turbulence measurement

D. Li, Q. Lin, J. Zhuang \& X. Wang

Experimental characterization of the near-wall turbulence in rough supercritical flows

E. Carvalho, R. Maia, R. Aleixo \& R. Ferreira

Mechanical model for velocity profile and flow resistance

G. Smart

Investigation of the impacts of coherent flow structures upon turbulence properties

in regions of fluvial scour

H. Maity \& B.S. Mazumder

Numerical modeling of complex solid-fluid flows with meshless methods

R. B. Canelas, R. M.L. Ferreira, A.J.C. Crespo \& J.M. Domínguez

A new immersed boundary method for simulating free-surface flows around arbitrary objects

X. Liu

Dispersion of a passive scalar in turbulent open channel flow

S. Bomminayuni, T. Stoesser \& N. Ruether

Spatial development of a constant-depth shallow mixing layer in a long channel

Z. Cheng \& G. Constantinescu

Prediction of compound channel secondary flows using anisotropic turbulence models

M.S. Filonovich, L.R. Rojas-Solórzano \& J.B. Leal

Flow in compound open-channels: Investigation of small-scale eddy viscosity variability using

a Smagorinsky turbulence closure model

C. Pham Van, E. Deleersnijder, D. Bousmar \& S. Soares-Frazão

Numerical study on secondary currents of the second kind in wide shallow open channel flows

R. Suzuki, I. Kimura, Y. Shimizu, T. Iwasaki \& T. Hosoda

Large Eddy Simulation of gravity currents moving on up-sloping boundaries

L. Ottolenghi, C. Adduce, R. Inghilesi, F. Roman \& V. Armenio

Density current propagation in a tidal river

M.R. Soliman, S. Ushijima \& S. Kantouch

Modeling of the spread of thermal pollution in rivers with limited data

M.B. Kalinowska \& P. M. Rowiński

for hydraulic jump and bore

T. Hosoda \& M.N. Langhi

In situ measurement of advection-dispersion processes in a torrential river, comparison

with numerical modeling

A. Hauet, G. Buannic, G. Antoine, M. Jodeau, M. Esteves \& F. Thollet

Discharge distribution and salt water intrusion in the Rhine-Meuse river delta network

N.E. Vellinga, M. van der Vegt, A.J.F. Hoitink \& P. Hoekstra

Two-dimensional hydrodynamic model of the St. Lawrence fluvial estuary

P. Matte, Y. Secretan \& J. Morin

Experimental investigation of a propeller jet induced velocity field

P. Nardone, P. Geisenhainer, Ka. Koll \& C. Di Cristo 
A study in hydraulic performance indices for sediment retention ponds

A. Farjood, B.W. Melville \& A. Y. Shamseldin

On the re-aeration coefficient in channels of complex shape

Prediction of velocity profile in river bends: A hydraulic geometry approach

S. Fasihi, E. Karrabi \& J. Attari

\section{A.2 Bed roughness and flow resistance}

Direct measurement of river-bed form resistance in rivers with sand waves

Y. Motonaga, A. Yorozuya, Y. Iwami \& M. Yamasaka

Near-bed flow over a fixed gravel bed

H. Friedrich, S. M. Spiller \& N. Rüther

Roughness parameters in shallow open-channel flows

O. Eiff, E. Florens \& F. Y. Moulin

Roughness coefficient determination and fine scale flow field characterisation

of fish baffles in HDPE slip lined culverts

J. Duguay, R. W.J. Lacey, E. Jaillet \& F. Floriani

Shallow gravel-bed river flows: The behaviour of the free surface and

the flow information contained within

A. Nichols, K. V. Horoshenkov \& S.J. Tait

Assessing surface DEM and roughness with a 3D-printed gravel bed

S. Bertin, H. Friedrich, P. Delmas, E. Chan \& G. Gimel'farb

J. Krick \& A. Sukhodolov

Simulation of the free surface and flow velocity in depth-limited flows over rough beds

E. Gabreil, S. Shao \& S. Tait

A numerical calculation method for flow in the presence of isolated boulders atop a rough

bed by using an enhanced depth integrated model with a non-equilibrium resistance law

T. Uchida, S. Fukuoka, A.N. Papanicolaou \& A.G. Tsakiris

Sphere drag revisited using Shuffled Complex Evolution algorithm

R. Barati, S. A. A. Salehi Neyshabouri \& G. Ahmadi

Field measurements of mean velocity and boundary shear stress with an acoustic

Doppler current profiler

J. Petrie, P. Diplas, M. Gutierrez \& S. Nam

Stage discharge prediction for highly sinuous meandering channels

S.S. Dash \& K. K. Khatua

Bathymetric changes, roughness and conveyance of a compound, regulated by groynes river channel during low and high water conditions

R. Banasiak, M. Krzyżanowski, J. Gierczak \& M. Wdowikowski

Explicit computation of bed form roughness for operational flood modelling,

a case study for the river Rhine

J.J. Warmink \& R. M.J. Schielen

\section{A.3 Vegetated flows}

Physically and numerically modelling turbulent flow in a patchy open channel

O.P. Folorunso, J. Bridgeman \& M. Sterling

Diverging flow and 3-D flow structure at leading edge and in interior

of submerged vegetation patch

T. Okamoto, M. Sanjou, S. Aoki, K. Toda \& I. Nezu 
Patches in a side-by-side configuration: A description of the flow and deposition fields

D. Meire, J. Kondziolka \& H.M. Nepf

LES of turbulent flows in open channel with patched vegetation zones

S. Yokojima, Y. Kawahara \& K. Matsubara

LES of flow past a submerged circular patch of vegetation

W.Y. Chang, G. Constantinescu \& W.F. Tsai

Relation between sandbar mode and vegetation expansion in sand-bed river

Y. Toda, S.N. Kim, T. Tsujimoto \& N. Sakai

Development of coherent structure and turbulence behind a finite-length emergent vegetation patch in open-channel flow

T. Okamoto, M. Sanjou, S. Aoki, K. Toda \& I. Nezu

Soil in braided rivers: An overlooked component of braided river morphodynamics

N. Bätz, E.P. Verrecchia \& S.N. Lane

Influence of vegetated bed material on erosional patterns of meandering rivers:

Preliminary experimental results

D. Termini

Flow-induced uprooting of young vegetation on river bedforms

K. Edmaier, B. Crouzy \& P. Perona

Modelling river flow responses to weed management

P. Rameshwaran, A. Sutcliffe, P. Naden \& G. Wharton

Field experiments in vegetated groyne fields

A.N. Sukhodolov \& T.A. Sukhodolova

Effects of trees along floodplain edges on the flow structure in compound meandering channel

Y. Kawahara, R. Tsubaki \& F.S. Nhavotso

Flow and bedload transport in a straight compound channel with vegetation roughened floodplains

M. Khademishamami, M.H. Omid \& J. Farhoudi

Numerical simulation of exchange flow between open water and floating vegetation

M. Tsakiri \& P. Prinos

Extending the canopy flow model for natural, highly flexible macrophyte canopies

T.I. Marjoribanks, R.J. Hardy, S. N. Lane \& D. R. Parsons

Dynamic drag modeling of submerged aquatic vegetation canopy flows

T.I. Marjoribanks, R.J. Hardy, S.N. Lane \& D. R. Parsons

Reynolds stress modeling of 3-D turbulent flow in a partially vegetated open channel

T. Koftis, P. Prinos \& C. Papakyritsis

Measurements of drag force of cylindrical rods and trees in a river

K. Shiono, E. Ferreira, J.H. Chandler, R. Wackrow \& T. Ishigaki

Spatially varying stem drag forces in vegetated mixing layers

L. Buckman, W.S.J. Uijttewaal, W.E. Penning \& J.T. Dijkstra

Experimental assessment of riverbed sediment reinforcement by vegetation roots

Analysis of equivalent Manning's roughness coefficient for trees vegetated on floodplain

K. Michioku, S. Kometani, T. Uotani, K. Kanda, Y. Irie \& K. Yanagida

Development and application of vegetation dynamics model for effective river management tasks in the Asahi River, Japan

K. Yoshida, S. Maeno, S. Matsuyama \& S. Fujita 


\section{A.4 Overbank flows and flood propagation}

A coupled surface-subsurface model of overbank flood flow and air entrapment

in a permeable floodplain

D. Pokrajac \& M.J.S. de Lemos

Celerity of kinematic wave in trapezoidal channel

S. B. Sokolov \& E. E. Egorov

A conservative strategy to couple 1D and 2D numerical models: Application to flooding simulations

M. Morales-Hernández, J. Murillo, A. Lacasta, P. Brufau \& P. García-Navarro

Unsteady characteristics of tsunami flow propagating over a land after overtopping seawall

H. Shirai \& T. Hosoda

2D shallow water GPU parallelized scheme for high resolution real-field flood simulations

R. Vacondio, F. Aureli, P. Mignosa \& A. Dal Palù

Analysis of depth averaged velocity in meandering compound channels

K. C. Patra, E. Padhi, L. Mohanty \& M. Patnaik

Prediction of energy loss along the non-prismatic reach of a compound channel using ANN

B. Naik, K.K. Khatua \& K. Miri

Composite roughness for rough compound channels

S. Pradhan \& K. K. Khatua

\section{A.5 Interaction between river flow and structures}

Numerical simulation of turbulent flow in open channel with groynes

Th.I. Koutrouveli, N.Th. Fourniotis, A.C. Demetracopoulos \& A.A. Dimas

Influence of submerged groynes on turbulence and flow structure at Sawmill Creek

in Ottawa, Canada

M.A. Ruta, C.D. Rennie, R.D. Townsend \& E.C. Jamieson

Submergence effect on flow and resistance due to a single groyne

A. Kadota \& W.S.J. Uijttewaal

Three-dimensional flow structures around large-scale groins on the flood plain

in the Kiso River

T. Ito \& A. Tominaga

Water surface response to flow through bridge openings

S. Kara, S. Mulahasan, T. Stoesser \& T.W. Sturm

Physics of shallow recirculation zones downstream lateral expansions

M. Chatelain, L. Han, N. Riviere \& E. Mignot

A comparison of wood-sediment-water mixture flows at a closed type and an open type of check dams in mountain rivers

F. Maricar \& H. Hashimoto

Log jam formation by an obstruction in a river

M.I. Rusyda, H. Hashimoto \& S. Ikematsu

Contribution of riprap to local turbulence at the downstream of a low-head sill

C.C. Wu, Y.Y. Wu, C.Y. Tao \& K.H. Wu

Representing skewed bridge crossing on 1-D and 2-D flood propagation models:

Compared analysis in practical studies

P. Costabile, F. Macchione, G. Petaccia \& L. Natale 
Experimental investigation on the flow field around a spur dike in a $90^{\circ}$ sharp bend

M. Mehraein, M. Ghodsian \& S.A. Najibi

Experimental study on the discharge released by Bric Zerbino Dam spillways

A. Fenocchi \& G. Petaccia

\section{B River morphology and sediment transport}

\section{B.1 Mechanics of sediment transport}

Particle motion of bed-load sediment moving over a smooth bed

J. Campagnol, F. Ballio, S. A. Hosseini Sadabadi \& H. Sazadul

Modelling the non-uniform sediment transport by means of the statistical moment approach

G. Rosatti, G. Garegnani \& A. Armanini

Experimental investigation on vertical size sorting using spherical glass beads

A.R. Dudill, P. Frey \& M. Church

Experimental study of sheet flow regime of sediment transport in a laboratory flume

T. Revil-Baudard, J. Chauchat, D. Hurther \& E. Barthélémy

Experiments in shear flow of granular-fluid suspension and dense mixture

A.M. Pellegrino, L. Schippa, E. Guazzelli \& O. Pouliquen

Effects of particle collisions on motions of mixed-size particles and bed structures

T. Fukuda \& S. Fukuoka

Laboratory study on transport of nonuniform bed material particles

M. Sajedi sabegh, M. Habibi, J. Soltani \& M. M. Vafaee

Shields diagram's extension for applications in steady non-uniform flows

J.S.A. do Carmo

Comparison of two models for bed load sediment transport in rivers

A. Paquier, B. Camenen, J. Le Coz \& C. Béraud

Numerical simulation of the sediment transport in the saltation regime

R. Barati, S.A.A. Salehi Neyshabouri \& G. Ahmadi

A natural-scale study of cohesive sediment transport: The Misa River case

M. Brocchini, A. Russo, J. Calantoni, A.H. Reed, M. Postacchini, C. Lorenzoni,

S. Corvaro, A. Mancinelli, G. Moriconi \& L. Soldini

Applicability of kinematic wave approximation to shallow mud-flows with a yield stress

C. Gisonni, M. Iervolino, A. Vacca \& C. Di Cristo

The role of interphase forces in submerged granular flows driven by gravity

E. Nucci, A. Armanini \& M. Larcher

Large eddy simulation of suspended sediment transport

M. Dallali \& V. Armenio

Ripple formation and sediment suspension events in unsteady depth varying open channel flow

F. Bagherimiyab, A. Roy \& U. Lemmin

Coherent structures in open channel flows with bed load transport over

an hydraulically rough bed

B.O. Santos, M.J. Franca \& R. M.L. Ferreira

Flow and turbulence characterization as an onset for assessing the stability of gravel beds

D. Duma, S. Erpicum, P. Archambeau, M. Pirotton \& B. Dewals

Sediment transport in steep channels with large roughness elements

T. Ghilardi, M.J. Franca \& A.J. Schleiss

Tracking bed load particles in a steep flume: Methods and results

J. Heyman \& C. Ancey 
Intense transport of bed load in steep flume

Bedload particle velocity in supercritical open channel flows

C. Auel, I. Albayrak \& R. M. Boes

Study of sediment transport using soft computing technique

H. Bonakdari \& I. Ebtehaj

Reconstruction of event-related bed-load transport processes in alpine catchments - application of $\mathrm{Tom}^{\text {Sed }}$ on a large spatial scale

B. Gems, M. Sturm, M. Aufleger \& J. Neuner

Influence of river ice break-up on stream hydraulics and sediment transport

S. G. A. Zare, S.A. Moore, C.D. Rennie, O. Seidou \& H. Ahmari

Analysis of suspended sediment transport data in the River Nile

B. A. Zaid, Ka. Koll, J.-U. Wiesemann \& A.S. Elzein

Quantification of suspended load, sinks and sources for a sediment budget

of the German river Rhine

N. Gehres, B. Brandstetter, G. Hillebrand, S. Vollmer, K. Banhold,

R. M. Frings \& H. Schüttrumpf

Non-uniform sediment input of the middle Yangtze River, China

H. Ge, R. Huang \& L. Zhu

\section{B.2 River morphology and morphodynamics}

Morphodynamic differences induced by different confluence angles

in widen confluences

S. Guillén, M.J. Franca, A.J. Schleiss \& A.H. Cardoso

Flow patterns in an open channel confluence with a small ratio of main channel

to tributary discharge

L. Schindfessel, S. Creëlle, T. Boelens \& T. De Mulder

Effect of bed elevation discordance in the main river on the confluence hydrodynamics

in $90^{\circ}$ straight-channels' confluences

D. Đorđević

Three dimensional flow field at confluent fixed-bed open channels

O. Birjukova, S. Guillen, F. Alegria \& A. H. Cardoso

Numerical simulation of local tributary widening impacts on hydro-morphological processes of river confluence using CCHE2D

M. Rostami \& S. Habibi

Characterization of confluences of free meander trains at the upper Amazon basin

R. Gutierrez, M. Choi, J. Abad \& H. Montoro

Trapping effect of fine sediment in Wando

K. Uno, G. Tsujimoto, T. Kakinoki \& N. Kazuuma

Sediment transport distribution along developing sand dunes

S. Naqshband, J.S. Ribberink, S.J.M.H. Hulscher \& D. Hurther

Modelling time dependent flow fields over three dimensional dunes

R.J. Hardy, T.I. Marjoribanks, D.R. Parsons, A.J. Reesink, B. Murphy,

P.J. Ashworth \& J.L. Best

Coupled numerical simulation of flow and bed and suspended sediment transport

over dunes based on the Immersed Boundary method

G. A. Leftheriotis \& A. A. Dimas

Objective method for ranking bedforms with a 3-dimensionality-index

F. Núñez-González, D. Hesse, B. Ettmer \& O. Link 
Occurrence and characterization of bed forms at the Danube to the east of Vienna

M. Liedermann, P. Gmeiner, M. Tritthart, M. Glas \& H. Habersack

Flow structure and large scale turbulence in an open channel bend of strong curvature with flat and deformed bed

G. Constantinescu \& M. Koken

The wall shear velocity, $u^{*}$, in fixed and eroded beds of $180^{\circ}$-curved open channel flow

B. A. Kironoto, B. Y. Istiarto, D. Legono, Sumiadi \& P.A.B. Sangging

Numerical modeling of dune progression in a high-amplitude meandering channel

A. Mendoza, D. Wang, J.D. Abad, E.J. Langendoen, P. Tassi \& K. El Kadi Abderrezzak

2D and 3D numerical simulations of morphodynamics structures in large-amplitude meanders

D. Wang, P. Tassi, K. El Kadi Abderrezzak, A. Mendoza, J.D. Abad \& E. Langendoen

Modulation of the flow structure by progressive bed forms in the Meandering Wabash River

J. Abad, C. Frias, K. Konsoer, J. Best, B. Rhoads, E. Langendoen \& M. H. Garcia

Ecomorphodynamic conditions for the emergence of river anabranching patterns

B. Crouzy, D. Wüthrich, P. Perona \& P. D’Odorico

Integration of a geotechnical model within a morphodynamic model to investigate

river meandering processes

Y.Y. Rousseau, M.J. Van de Wiel \& P.M. Biron

Numerical studies on bed variations under interactions of vegetation and bank strength

T. Uchida, I. Kimura, Y. Shimizu \& S. Kawamura

Stability analysis on periodically changing of channel width

$Y$. Watanabe \& K. Hasegawa

A diffusive 1D model for the evolution of a braided network subject

to varying sediment supply

M. Redolfi \& M. Tubino

Morphodynamic modelling of a tortuous meandering clay bed river using Delft3D:

Stillwater Creek, Ottawa

P. Parsapour-Moghaddam \& C.D. Rennie

Variation of the bankfull area in a braided reach of the LYR over the past 30 years

X.J. Li, J.Q. Xia \& J. Li

Sediment transport and bedform development in the lee of bars: Evidence from fixed- and partially-fixed bed experiments

A.J.H. Reesink, D.R. Parsons \& R.E. Thomas

Characteristics of subsurface water flow influenced by formation process of gravel bar

M. Obana, T. Chibana \& T. Tsujimoto

A new equation for alternate bar length

A.A. Boraey \& A. M. Ferreira da Silva

Spatial distribution of porosity of bed material, bed strength and size distribution

of bed material on bars

H. Takebayashi, M. Fujita, R. Kamito \& Y. Samoto

of mathematical models using fields observations

L. Adami \& W. Bertoldi \& G. Zolezzi

Modelling river bed form dynamics: Large scale application

S. Giri, S. Yamaguchi, M. Nabi \& Y. Shimizu 
Sensitivity of morphodynamic simulations due to input variability-implications on sedigraph estimations due to limited data

S. Jocham, R. Klar, S. Achleitner \& M. Aufleger

Numerical modelling of morpho-dynamic processes with multi-thread flows

J. Sun, B. Lin \& H. Yang

Numerical simulation for bed aggradations due to sediment overloading in alluvial channels

A.L. Qureshi \& A. Baloch

Multi-scale modelling of river morphodynamics

M. Nabi, S. Giri, T. Iwasaki, I. Kimura \& Y. Shimizu

Recovering Elder's equation: A new view on river morphology

A.J. Constain, D.J.M. Fernández, J.L.C. Rivera \& C.A. Peña-Guzmán

Temporal bed adjustments to a series of water pulses in gravel bed rivers

C. Ferrer-Boix \& M.A. Hassan

River morphological evolution in earthquake-hit region: Effects of floods

and pulsed sediment supply

C.G. An, X.D. Fu \& G. Parker

Sediment transport, sorting and three-dimensional flow patterns in pool-riffle sequences:

Implications for self-maintenance

E. Bayat, J.F. Rodríguez, G.A.M. de Almeida \& P. Saco

River rejuvenation for a sediment-laden torrent from the viewpoint of river morphology

C.C. Wu \& P. H. Wang

Quasi-stable channel morphology in response to hydromodification

B.D. Plumb \& W.K. Annable

Simulation of local river widenings - a matter of 1D or 2D modelling?

Th. Berchtold, V. Weitbrecht, D. Vetsch \& R. M. Boes

Analysis of morphological changes in rivers

M. Gharbi, A. Soualmia, D. Dartus \& L. Masbernat

Comparison of morphological predictions in the Lower Rhine River by means

of a 2-D and 3-D model and in situ measurements

L. Backhaus, T. Brudy-Zippelius, T. Wenka \& J. Riesterer

Analysis of the Solís Chico river mouth migration

C. Chreties, S. Solari, G. López \& L. Teixeira

Analysis of the estuarine sediment of the Taimali River in Taiwan

Wei-Po Huang, John Z. Yim \& Yi Jiun Liao

The effect of potential discharges on the stability of the Rosetta promontory, Egypt

A. Masria, M. Iskander, A. Negm \& O.C. Saavedra

\section{B.3 Local scour and erosion processes}

Clear water scouring around bridge piers and the phenomenological theory of turbulence

C. Manes

Local scour at bridge piers founded in coarse-bed streams

D. C. Froehlich

Spatiotemporal changes in bed elevations with turbulence around submerged cylinders

embedded in sand beds

B.S. Mazumder, K. Sarkar \& C. Chakraborty

Temporal evolution of live-bed pier scour

J.H. Hong, H. W. Wang, Y.C. Wang, S.C. Li \& Y.M. Chiew 
Experimental and computational study of local scour pool around finite patches of vegetation

H.S. Kim, I. Kimura \& Y. Shimizu

A preliminary study on scour at submerged weirs in live bed conditions

D. Guan, B.W. Melville \& H. Friedrich

Experimental and numerical study of the scour process around a slit weir

K. Ota \& T. Sato

An experimental and numerical study on the spatial and temporal evolution

of a scour hole downstream of a rigid bed

G. Dodaro, A. Tafarojnoruz, F. Calomino, R. Gaudio, F. Stefanucci,

C. Adduce \& G. Sciortino

Equilibrium scour hole downstream of an apron: A model

A. Sarkar

Numerical modeling on response of fluvial geomorphology to weir removal

S.N. Kim, Y. Toda \& T. Tsujimoto

The dynamic of streams equipped with Check Dams

G. Piton \& A. Recking

Influence of a single submerged groyne on the bed morphology and the flow field

R. Möws \& Ka. Koll

Laboratory analysis of armor layer development in a local scour around a groin

G.T. Török, S. Baranya, N. Rüther \& S. Spiller

Riverbed layering impact on scour at the abutments

B. Gjunsburgs, E. Govsha \& G. Jaudzems

Spatial and temporal variations in bed morphology at river contractions

G. Oliveto \& M.C. Marino

Location of the maximum scouring depth at the outlet of partially-blocked and non-blocked box culvert

S. Sorourian, A. Keshavarzi, J. Ball \& B. Samali

Investigation of the effective parameters sensitivity with respect to both shear and beam-type failures in overhanging riverbanks

A. Samadi, E. Amiri-Tokaldany \& S.E. Darby

Experimental study of cantilevered riverbank stability

E. Amiri-Tokaldany, A. Samadi \& M.H. Davoudi

Flow structure and bed deformation around a sphere on movable bed

A. Tominaga

Scour on alluvial bed downstream of falling jets

V. Fiorotto, E. Caroni \& S. Calligaris

Clear-water bridge scour under triangular-shaped hydrographs with different peak discharges G. Bombar

Verification of equation for non-deposition sediment transport in flood water canals

H. Bonakdari \& I. Ebtehaj

Scour development caused by propeller jet of moving vessels

P. Geisenhainer \& Ka. Koll

Application and validation of sediment erosion models to time dependent wall shear stresses around a wall-mounted circular cylinder

W. Schanderl, O. Chmiel, P. Huttner, S. Zischkale \& M. Manhart 


\section{B.4 Geomorphic unsteady flows}

Numerical simulation of snow avalanches as a Bingham fluid flow using SPH method A.M. Abdelrazek, I. Kimura \& Y. Shimizu

Debris flow monitoring in the French Alps

C. Bel, F. Liébault, H. Bellot, F. Fontaine, D. Laigle \& O. Navratil

Unsteady 2D flow over mobile bed with variable density

C. Juez, J. Murillo \& P. García-Navarro

Hydro-morphologic modelling for different calamitous scenarios in a mountain stream

A. Radice \& S. M. Elsayed

Modelling bedload transport for mixed flows in presence of a non-erodible bed layer

G. Corestein, E. Bladé \& D. Niñerola

The response of bed-load sediment transport and bed evolution under unsteady hydrograph flows

L. Wang, A. Cuthbertson, G. Pender \& Z. Cao

Morphological changes in River Nile at Bani-Sweif for probable flood flow releases

A.S. Foda \& A. M.A. Sattar

\section{B.5 Dyke and dam erosion}

Laboratory experiments on dam-break flow of water-sediment mixtures

Y. Ozeren, R. Aleixo, M. Altinakar \& D. Wren

Spatial dike breach: Accuracy of photogrammetric measurement system

P.-J. Frank \& W.H. Hager

Mechanism of embankment dam breach

D. Verma, B. Setia \& V.K. Arora

Dike erosion due to a sudden-wave overtopping: Preliminary results

S. Evangelista, A. Leopardi \& M. Mingarelli

Limitations of the shallow water assumptions for problems involving steep slopes:

Application to a dike overtopping test case

S. Van Emelen, Y. Zech \& S. Soares-Frazão

C. Di Cristo, S. Evangelista, A. Leopardi, M. Greco \& M. Iervolino

Tailings dam-break flow analysis by means of a combined PIV-PTV tool

R. Aleixo, Y. Ozeren \& M. Altinakar

One-dimensional and two-dimensional hydraulic-numerical modeling of dam break waves

A. Bornschein

\section{River engineering and restoration}

\section{C.1 Flow management and flood control}

Floods in the Guadalquivir river (Southern Spain)

P. Bohorquez, V. Aranda, J. Calero, F. García-García, P.A. Ruiz-Ortiz,

T. Fernández \& C. Salazar 
A mobile bed 1D numerical model to support Red River (VietNam) basin management

D. Bernardi \& L. Schippa

Unraveling the contribution of wind, sea level and discharge to design water levels

in the Dutch delta

R.M.J. Schielen, A. Bomers \& D. Kroekenstoel

Hydrodynamics of Ribarroja Reservoir (Ebro River, Spain): Water temperature,

water velocities and water age

M. Arbat-Bofill, M. Sánchez-Juny, E. Bladé, D. Niñerola, J. Dolz \& A. Palau

The numerical investigation of the effect of subsequent check dams on flood peaks and the time of concentration using the MIKE 11 modeling system (Case study:

Golabdareh catchment, Iran)

P.H. Namadi, B. Saghafian \& M. Rostami

Flood disaster and training of River Ganga and its two tributaries

in India - some case study

S.K. Mazumder \& K.N. Keshri

The Bisagno River diversion

M. Ferrari, M. Belicchi, D. Cerlini, U. Majone, S. Venturini, A. Marchi, A. Galli,

U. Galli \& S. Pinasco

Applying river stage forecasting for early inundation warning

M.-H. Hsu, J.-C. Fu \& W.-H. Teng

The "Isère Amont" project: 16 expanding flood areas along the river

O. Manin, A. Le Peillet \& L. Boutonnier

Semi-automatic conceptual model identification and calibration tool

for river hydraulic computations

V. Wolfs, P. Meert \& P. Willems

New computation method for flood flows and bed variations in a low-lying river with complex river systems

K. Tabata \& S. Fukuoka

Lateral flood discharge at rivers: Concepts and challenges

M. Bühlmann \& R. M. Boes

Mitigation measures for unsteady flow effects on riverbeds during hydropower peaking

S. Spiller, N. Rüther \& H. Friedrich

A study on selection of probability distributions for at-site flood frequency analysis in

Mahanadi river basin, India

N. Guru \& R. Jha

Iowa watersheds project: Planning and assessment of flood reduction strategies

in agricultural watersheds

N.W. Thomas, L.J. Weber \& N.C. Young

Freeboard allowance at rivers - experiences from Germany

R. Pohl

Managing materials across the Isere river and "Isere Amont" works

O. Manin, J.-F. Frezet \& L. Boutonnier

Large wood dynamics in a wide mountain river: The Czarny Dunajec, Polish Carpathians

V. Ruiz-Villanueva, M. Stoffel, B. Wyżga, P. Mikuś \& Z.W. Kundzewicz

Effect of Black Hole Dams in the Eastern Nile River Basin: Changes in water quantity and quality of downstream countries

S.A. Kantoush 


\section{C.2 Risk mitigation and assessment in river basins}

One-dimensional flood inundation modeling and sediment transport characterization

for a potential mining site in southern Virginia, USA

C.F. Castro-Bolinaga \& P. Diplas

Site selection for sand and gravel mining using an integrated GIS/MCDM approach

A. Effati, A. M. Malek, S. Seyf \& A. Karaji

The Romanche Séchilienne project, an integrated approach to river development

M. Grenier, T. Monier \& C. Moiroud

Sediment management measures for river restoration and flood protection

in alpine valleys

B. Roquier, J. Dubois \& J.-L. Boillat

Estimating the combined effect of flood mitigation measures

F. Huthoff, J. Udo, H. Barneveld, M. Bakker \& N. Asselman

PMP-PMF and their occurrence probability in alpine region by 2-3D modelling

J.A. Hertig, R. G. Receanu \& J. M. Fallot

\section{C.3 Flow monitoring and remote sensing methods}

Bedload grain size estimation from the indirect monitoring of bedload transport with Swiss plate geophones at the Erlenbach stream

C.R. Wyss, D. Rickenmann, B. Fritschi, J.M. Turowski, V. Weitbrecht \& R.M. Boes

M. Klösch \& H. Habersack

Monitoring of sediment transport processes for determining future trends

J. Schneider, M. Redtenbacher, G. Harb, O. Sass, J. Stangl, A. Gobiet, G. Heinrich \& S. Tani

Gravity wave effects on the calibration uncertainty of hydrometric current meters

M.A. de Huи \& B. Wüthrich

Remote monitoring of volumetric discharge based on surface mean and turbulent metrics

E. Johnson \& E. Cowen

Acoustic sediment flux observations on the Fraser River, Canada

D. W. Haught, J.G. Venditti \& M. Church

A quality analysis of the Vectrino II instrument using a new open-source MATLAB toolbox and 2D ARMA models to detect and replace spikes

B. MacVicar, S. Dilling, J. Lacey \& K. Hipel

Image-based velocity and discharge measurements in field and laboratory river engineering studies using the free Fudaa-LSPIV software

J. Le Coz, M. Jodeau, A. Hauet, B. Marchand \& R. Le Boursicaud

Evaluation of $2 \mathrm{D}$ river flow simulation with the aid of image-based field velocity measurement techniques

I. Fujita, G. Kumano \& K. Asami

Three dimensional flow analyses for accuracy estimation of floats flow measurement

A. Kadota \& S. Okada

Operational river velocity surveillance at whole reach-scale by implementing time-of-arrival algorithms on upstream-downstream conductivity signals

D. Petrovic, I. Vulpe, J.-P. Vanderborght \& M.A. Verbanck

Using airborne hydromapping to study an alpine torrent

W. Dobler, R. Baran, F. Steinbacher, M. Ritter \& M. Aufleger 
Wetted width of Norwegian rivers - results of a pilot study

Stream temperature forecasting by means of ensemble of neural networks: Importance of input variables and ensemble size

M.J. Napiorkowski, A.P. Piotrowski \& J.J. Napiorkowski

Decomposition of a cloud of gaugings into hydraulically homogeneous families for the tracing of the rating curves by using existing segmentation procedures

T. Morlot, C. Perret \& A.-C. Favre

Harmonizing water and energy, available tools from the AIM Alpine Space in Movement project

M.A. Peviani, A. Danelli \& M. Cesca

\section{C.4 Protection against local scour and erosion}

Studies on the effect of an upstream pier as a scour protection measure

of a downstream bridge pier

S.K. Khaple, P.R. Hanmaiahgari \& S. Dey

Application of collars as scour countermeasure at various contraction ratios caused by two spill through abutments

M. Koken, M. Gogus \& K. Yilmaz

Designing rock riprap falling aprons to protect bridge piers and abutments

D. C. Froehlich

Effect of compressed riprap thickness on the stability of river banks

M. Jafarnejad, M.J. Franca, M. Pfister \& A.J. Schleiss

Predicting stable river bank angle after planar mass failure

E.A. Tokaldany, M. Rezaie-Mayani \& M.H. Davoudi

Experimental assessment of scouring and deposition processes around arrays

of permeable gabion groynes

M. Romero, N. Ballesteros \& V. Lucana

Scour characteristics downstream of grade-control structures

S. Pagliara \& S. M. Kurdistani

Experimental estimation of rockfill protection downstream stilling basins

R. A. Lopardo

Evaluation of scour downstream of riprap aprons on low-head ogee spillways

C. Biering, S.H. Hong, T. Sturm, K.S. Yoon \& J.A. Gonzalez-Castro

Effect of riprap protection in controlling local scour at the toe of a groundsill

C.-C. Wu, P.C. Huang, W.L. Liao, Y.C. Chung \& T.S. Hsu

Sediment transport and morphodynamics in an urbanized river: The effect of restoration on sediment fluxes

M. Chapuis, V. Bevan, B. MacVicar \& A. G. Roy

River management with submerged vanes

\section{A.J. Odgaard}

Development and implementation of a fish-friendly river bed stabilization

U. Stephan, M. Hengl \& M. Manser

River stabilization with groynes in the Western Cape, South Africa

H.E. King

Experimental study on effects of grain size in failure process of rubble mound spur-dike under submerged conditions

H. Haghnazar, R. Sadeghi, S. A.A. Salehi Neyshabouri \& M. Ghodsian 


\section{C.5 Physical and numerical modelling in river engineering}

Experimental measurements of flow and sediment transport through bottom racksinfluence of gravels sizes on the rack

L.G. Castillo, J.T. García \& J.M. Carrillo

Experimental parametric study of energy dissipater design in natural rivers

Z. Vecsernyés, M. Destrieux, N. Andreini \& J.-L. Boillat

Calibration of the physical reduced scale model of Xingu River bed for a study of

Belo Monte Hydroelectric Plant

F.R. Terabe, J.R.M. Almeida, J.J. Ota, I.I. Müller, G.D. Goretti,

J.C. de F. Guimarães \& C.R. Vareta

A simple physically-based model for predicting sand transport dynamics

in the Lower Mekong River

B. Camenen, J. Le Coz, G. Dramais, C. Peteuil, T. Fretaud, A. Falgon,

P. Dussouillez \& S.A. Moore

Mean flow structures and control for suitable bed morphology around

successive groynes

A. Kadota \& C. Asayama

Implicit finite volume solution of the bidimensional Shallow Water Equations

in unstructured meshes: Application to river flow

J.M. Martí \& F.A. Sánchez

Investigating grid-size dependency in coupled surface-subsurface hydraulics

K. Shaad \& P. Burlando

Variable-grid numerical model for river closure

F. Yongyang, Z. Wei, L. Lin, L. Ming \& Z. Ming.

How to determine the erosion risk of contaminated cohesive sediments best?

Putting in situ and laboratory practices to the test

M. Noack, S. U. Gerbersdorf, S. Wieprecht, G. Hillebrand \& P. Kasimir

A Matlab framework for mathematical modeling in geosciences

N. Zimmermann, S. Buitrago, C. Gullentops \& J. Blanckaert

Spreadsheet tools for river evaluation, assessment and monitoring

D. Mecklenburg, A. Ward, J. Witter \& J. D'Ambrosio

Evaluation of water intake location suitability using hydrodynamic modeling

Two-dimensional modeling of multi-grain sediment transport in extreme events

D. Farshi, D. Job, J. Trösch \& B. Faust

Simulation of bedload transport in the Hasliaare River with increased

sediment input

D. Rickenmann, F.U.M. Heimann, J.M. Turowski, C. Bieler,

M. Böckli \& A. Badoux

Reactivation of Klingnau reservoir sidearm: Numerical simulation of sediment

release downstream

A. Amini, P. Heller, G. De Cesare, A.J. Schleiss, N. Kräuchi \& P. Rötheli

Variation of river flow due to the 2011 Tohoku Tsunami

M. Roh, M.B. Adityawan \& H. Tanaka

The influence of flood sequencing on the morphology and bed composition

of the American River, California, USA

D. Pender, H. Haynes, G. Pender \& A. Shvidchenko 
Effects of large-scale rubber farm on soil erosion and river bed material in the upper Mekong Basin

X. Zhou, Z. Wang, B. Yu \& L. Seitz

\section{C.6 River habitat management}

Habitat numerical modelling to assess fish shelter design under hydropeaking conditions R.Z. Almeida, I. Boavida \& A. N. Pinheiro

Enhancement of habitat heterogeneity by placement of boulders in streams

A. Hamuy-Blanco \& C.S. James

Relationship between scenery of flow ecology habitat and physical environment

R. Lopa \& Y. Shimatani

Spatiotemporal patterns of geomorphological processes determine characteristics of riverine habitat heterogeneity

M. Hyodo, Y. Takemon \& T. Sumi

Macquarie River floodplain flow modeling: Implications for ecogeomorphology

S. G. Sandi Rojas, J.F. Rodríguez, P. Saco, G. Riccardi, L. Wen, N. Saintilan, H. Stenta,

F. Trivisonno \& P.A. Basile

Impacts by dams: From water quality modelling to management optimization

M.J. Kunz \& A. Wüest

Research on aquatic ecology in the Naban River and restoration suggestions

N. Zhao, Z. Y. Wang, M.Z. Xu, L.J. Han \& X.D. Zhou

Creek restoration on an industrial site in southern Québec, Canada

N. Stämpfli, T. Winhold \& P. Groleau

Water holding capacity and runoff load at the Anmon River in the Shirakami-Sanchi

World Heritage Site

A. Marui, A. Kudo, M. Izumi \& E. Kurashima

Habitat restoration in an urban channel - experiences from monitoring of a pilot action

R. Mohn, N. Vosswinkel, M. Göke \& H.W. Riss

Morphodynamics restoration of the Old Rhine through controlled bank erosion:

Concept, laboratory modeling, and field testing and first results on a pilot site

D. Aelbrecht, A. Clutier, A. Barillier, K. Pinte, K. El-Kadi-Abderrezzak,

A. Die-Moran, F. Lebert \& A. Garnier

Study effects of river locks on Karoon and Bahmanshir Rivers to control salinity intrusion and developing of Abadan region in Iran

M. Daliry

The recovery of water temperature and Dissolved Oxygen in the downstream river

of a stratified reservoir: A field investigation and experiment

C. Zhang, Z. Wang, N. Zhao, Z. Li \& W. Li

\section{C.7 Eco-hydraulics}

Analysis of flow patterns in vertical slot fishways

M. Musall, C. Schmitz, P. Oberle, F. Nestmann, M. Henning \& R. Weichert

Refurbishing an old fish pass: Physical and numerical modeling

D. Bousmar, G. Zorzan, A. Gillet, J. Lopez Delhoulle, A. Baugnée \& J.C. De Greef

J. Stamm, U. Helbig \& C. Schulz

Hydraulic modeling of nature-oriented fishways and fluvial structures

R. Czerny, P. Oberle \& F. Nestmann 
Temporal and spatial hydrodynamic variability in a gravel-bed river: Measurement, characterization, and significance for spawning salmonids at the riffle scale

V.G. Lounder \& W.K. Annable

Simulating High-Flow Effects (HFE) on river deformation and rainbow trout

(Oncorhynchus mykiss) habitat

W. Yao, S. Bamal \& P. Rutschmann

Simulating dam effects on river deformation and rainbow trout (Oncorhynchus mykiss)

population number

W. Yao, V. Kumar \& P. Rutschmann

The temporal variability of hydraulic variables depending on morphology

M. Paternolli \& W. Gostner

Effects of large wood on morphology, flow and turbulence in a Lowland River

K. Blanckaert, R. Han, F. Pilotto \& M. Pusch

Wood density assessment to improve understanding of large wood buoyancy in rivers

V. Ruiz-Villanueva, M. Stoffel, H. Piégay, V. Gaertner \& F. Perret

\section{C.8 Navigation waterways}

Connecting a tributary stream into the Canal du Centre thanks to a settling basin

in Obourg, Belgium

C. Swartenbroekx \& D. Bousmar

An integral feasibility study of a new weir in the Lower Rhine

H. G. Tuin, H. G. Voortman, R.A.J. van de Kamp, W. Seinen, J.K. Vrijling \& A. van der Toorn

Research on navigation-obstruction with complex boundary and its counter measures in middle reaches of the Yangtze River

A. Pengsongbo, B. Liulin, C. Huangchengtao \& D. Liufengyang

Assessment of the function of engineering measures to improve the navigability

of the Danube - a comparison between different modelling approaches

Y. Huismans, M.F.M. Yossef \& G. Deák

Research on the normal water level and its effect on waterway condition in the cascade navigation-power junction

$X$. Feng \& Y. Li

Keyword index

Author index 
This page intentionally left blank 


\section{Preface}

Nature is not to be trifled with, she is always true, always earnest, always severe; she is always right, and the faults and errors are always those of man (Goethe).

Hydraulic engineers responsible for the planning of river training and restoration works should bear well in mind this quotation from Goethe. Reliable and sustainable protection against floods can only be assured by hydraulic structures that preserve the natural character of a watercourse. Accordingly, modern river engineering must take a river's natural forces and behaviour into account. For example, attempts to straighten a meander that has developed naturally may be dangerous: in extreme flood conditions, if not earlier, the apparently tamed river will recall and reoccupy the space to which it is entitled.

The world is like a river, running along in its bed, this way and that, forming sandbanks by chance and then being forced by these to take a different course. Whereas this all proceeds smoothly and easily and gradually, the river engineers have great difficulties when they seek to counteract this natural behaviour (Goethe).

Goethe (once again) recognized that the dynamics of a river can only be controlled to a limited extent by channel modifications and rigid river training works. The term "dynamics" refers to variations in hydromorphology over space and time due to flood discharges and sediment transport. These processes regularly lead to the destruction of habitats, especially in riparian areas, and the creation of space for new habitats. Dynamic watercourses require a considerable amount of space. For example, naturally meandering rivers may migrate laterally within a belt of roughly five to six times the width of the channel bed. In the valleys of the Alps and Pre-Alps, rivers originally required the entire valley floor.

As well as providing flood protection, watercourse alterations carried out over the last two centuries were designed to reclaim land for development and agriculture. Efforts were thus made to impede the dynamics: rivers and streams were channelized, and channel bed widths were optimized with regard to sediment transport. This resulted in monotonous watercourses, with almost no variation in hydraulic or morphological characteristics.

Today's challenge for river engineers, in close collaboration with environmental and ecological scientists, is to restore the channelized river under the constraints of high urbanization and limited space. The behaviour of river systems is a result of the complex interaction between flow, sediments, morphology and biota. Furthermore rivers are often used as a source for water supply and energy production as well as a waterway for transportation.

During the 7th International Conference on Fluvial Hydraulics "River Flow 2014" at École Polytechnique Fédérale de Lausanne (EPFL), Switzerland, scientists and professionals from all over the world addressed these challenges and exchanged their knowledge regarding fluvial hydraulics and river morphology. Past conferences, as well as the current one, organized under the auspices of the Committee on Fluvial Hydraulics of the International Association for Hydro-Environment Engineering and Research (IAHR), witnessed a significant increase in participation of our community of river engineers and researchers, confirming the need for such a forum.

The Local Organizing Committee of River Flow has received more than 650 abstracts, of which more than 630 were aligned with the conference's topics. Subsequently, 410 papers were submitted by engineers and researchers. The International Scientific Committee has finally selected 343 contributions (from authors originating from 43 countries) to be included in the Proceedings and in the separate book documenting the special session on Reservoir Sedimentation. Of these about 2/3 were considered for long oral presentation (15 minutes) and 1/3 were selected for short presentation ( 3 minutes) and poster. The overall very high quality of the contributions demonstrates the dynamism of the scientific and professional community working on fluvial hydraulics.

A traditional distinctive feature of River Flow conferences has been the organisation of Master Classes the day before the formal opening of the conference. Master Classes present a unique opportunity for $\mathrm{PhD}$ and MSc students and young researchers to address their research with renowned senior scientists, 
meet peers working on similar topics and identify possible collaborations for the continuation of their work. At River Flow 2014 six Master Classes were conducted by 13 masters, enrolling 65 students from 15 countries. This confirms the vitality of the fluvial hydraulics community contributing to ensure the sustainability of IAHR.

Prof. Dr. Anton J. Schleiss, Conference Chairman Dr. Giovanni De Cesare, Co-Chairman Dr. Mário J. Franca, Co-Chairman Dr. Michael Pfister, Co-Chairman 


\section{Acknowledgements}

The success of a conference depends above all on the quality of the contributions of the participants. We are therefore grateful to all researchers and practitioners working in the river-related disciplines who made such a large number of contributions to River Flow 2014. The International Scientific Committee verified the pleasingly high quality of the submitted contributions when performing an in-depth review of the manuscripts. We are very grateful to its members for their excellent review work, rare in conferences, despite the limited time available. A major concern of the River Flow conferences is to attract young researchers. In this light we specially thank all students that applied to the Master Classes as well as all Masters who accepted the invitation to lecture in our conference and who attracted so many students.

A conference, involving numerous students at a reduced fees, can only be financially viable with some significant level of sponsorship. We acknowledge the support of the Swiss Federal Office for the Environment, BG Consulting Engineers, and Hydro Exploitation SA as gold sponsors for the proceedings and the conference. The existence of numerous Master Classes and the need to cover the expenses of distinguished Masters was only possible with the support of Swiss National Science Foundation (SNSF). Finally, further support to the Conference was given by the silver sponsors e-dric.ch, IM \& IUB Engineering, Basler \& Hofmann, AquaVision Engineering, and Met-Flow SA.

River Flow 2014 benefits from the experience of the organizers of previous editions and we thank them for the fruitful advices. The success of River Flow is a result of the excellent teamwork within the LOC supported by all staff of the Laboratory of Hydraulic Constructions (LCH), who invested considerable time during two years for the preparation of the conference. A special thanks goes to the conference secretariat ensured by Mrs. Scarlett Monnin and Mr. Gesualdo Casciana.

Finally the involvement of IAHR and the Committee on Fluvial Hydraulics was fundamental for the divulgation of the conference; and for their efforts we express our gratitude.

The Local Organizing Committee of River Flow 2014 
This page intentionally left blank 


\section{Organization}

\section{MEMBERS OF THE INTERNATIONAL SCIENTIFIC COMMITTEE}

Walter H. Graf, Switzerland (Honorary Chair)

Jorge D. Abad, USA

Jochen Aberle, Norway

Claudia Adduce, Italy

Mustafa Altınakar, USA

Christophe Ancey, Switzerland

William K. Annable, Canada

Aronne Armanini, Italy

Francesco Ballio, Italy

Roger Bettess, UK

Koen Blanckaert, China

Robert Michael Boes, Switzerland

Didier Bousmar, Belgium

Benoît Camenen, France

António Heleno Cardoso, Portugal

Hubert Chanson, Australia

Qiuwen Chen, China

Yee-Meng Chiew, Singapore

George S. Constantinescu, USA

Ana Maria da Silva, Canada

Andreas Dittrich, Germany

Rui M.L. Ferreira, Portugal

Massimo Greco, Italy

Willi H. Hager, Switzerland

Hendrik Havinga, The Netherlands

Hans-B. Horlacher, Germany

David Hurther, France

Martin Jäggi, Switzerland

Juha Järvelä, Finland

Sameh Kantoush, Egypt

Katinka Koll, Germany

Bommanna G. Krishnappan, Canada

Stuart Lane, Switzerland

João G.A.B. Leal, Norway

Angelo Leopardi, Italy
Danxun Li, China

Juan-Pedro Martín-Vide, Spain

Bijoy S. Mazumder, India

Bruce W. Melville, New Zealand

Emmanuel Mignot, France

Rafael Murillo, Costa Rica

Heidi Nepf, USA

A. Salehi Neyshabouri, Iran

Vladimir Nikora, $U K$

Helena I.S. Nogueira, Portugal

Nils Reidar Olsen, Norway

André Paquier, France

Piotr Parasiewicz, USA

Michel Pirotton, Belgium

Dubravka Pokrajac, UK

Sebastien Proust, France

Wolfgang Rodi, Germany

Jose Rodriguez, Australia

Pawel M. Rowinski, Poland

André Roy, Canada

Koji Shiono, UK

Graeme M. Smart, New Zealand

Sandra Soares-Frazão, Belgium

Thorsten Stoesser, $U K$

Mutlu Sumer, Denmark

Simon Tait, $U K$

Aldo Tamburrino, Chile

Wim S.J. Uijttewaal, The Netherlands

Zhaoyin Wang, China

Volker Weitbrecht, Switzerland

Silke Wieprecht, Germany

Farhad Yazdandoost, Iran

Yves Zech, Belgium

\section{MEMBERS OF THE IAHR COMMITTEE ON FLUVIAL HYDRAULICS}

Andreas Dittrich, Technical University of Braunschweig, Germany, Chair

Jose Rodríguez, The University of Newcastle, Australia, Vice Chair

Mustafa Altınakar, The University of Mississippi, USA, Past Chair

André Paquier, Irstea, France, Member

Sandra Soares-Frazão, Université Catholique de Louvain, Belgium, Member

Subhasish Dey, Indian Institute of Technology, India, Member 
Angelo Leopardi, Università Degli Studi Di Cassino E Del Lazio Meridionale, Italy, Member Shaohua Marko Hsu, Feng Chia University, Taiwan, Member

Rui M.L. Ferreira, Instituto Superior Técnico, Portugal, Co-opted member

George Constantinescu, University of Iowa, USA, Co-opted member

Mário J. Franca, École Polytechnique Fédérale de Lausanne, Switzerland, Co-opted member

\section{MEMBERS OF THE LOCAL ORGANIZING COMMITTEE}

Anton J. Schleiss, EPFL, Conference Chairman

Giovanni De Cesare, EPFL, Co-Chairman

Mário J. Franca, EPFL, Co-Chairman

Michael Pfister, EPFL, Co-Chairman

Scarlett Monnin, EPFL, Secretary

Gesualdo Casciana, EPFL, Secretary 
Sponsors

\section{SUPPORTING INSTITUTIONS}
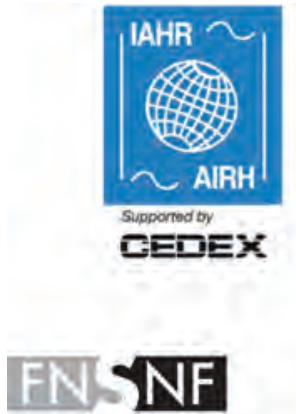

SWiss National SCIEnCE Foundation
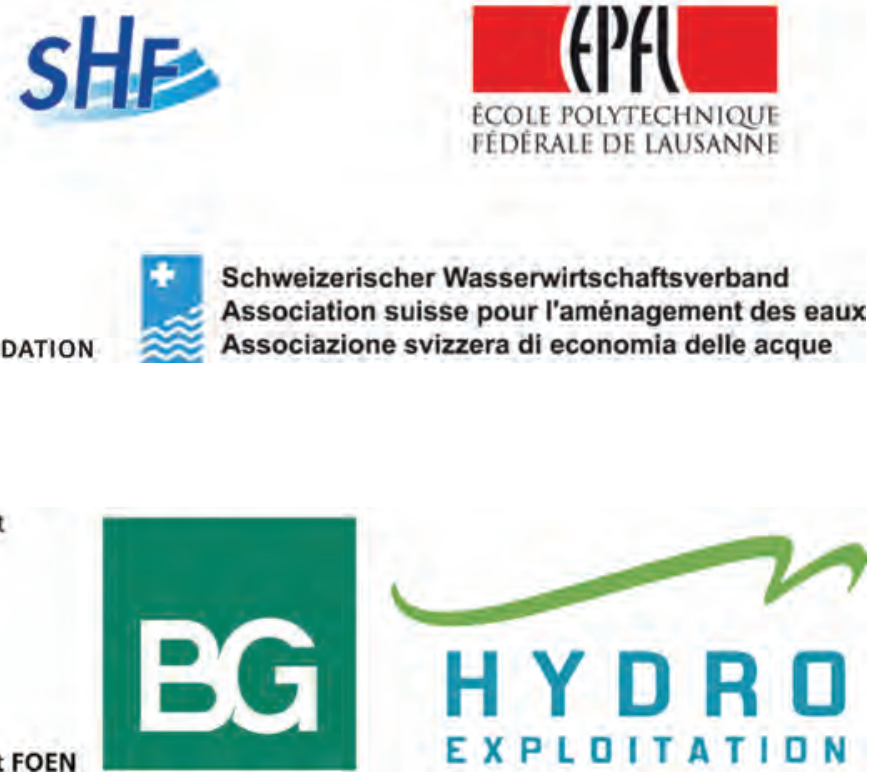

E X P L DITATIDN

Schweizerischer Wasserwirtschaftsverband Association suisse pour l'aménagement des eaux Associazione svizzera di economia delle acque
ĖCOLE POLYTECHNIQUE FÉDERALE DE LAUSANNE

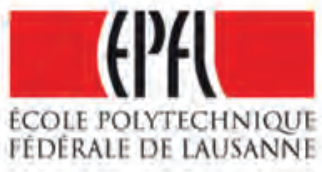

SILVER SPONSORS

\section{Basler\&Hofmann}

\section{GOLD SPONSORS}

Schweizerische Eidgenossenschaft

Confédération suisse

Confederazione Svizzera

Confederaziun svizra

Swiss Confederation

Federal Office for the Environment FOEN

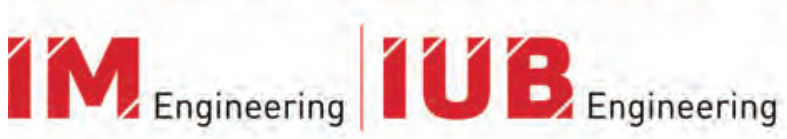

YAMET-FLOW

\section{ดquaVision} Engineering

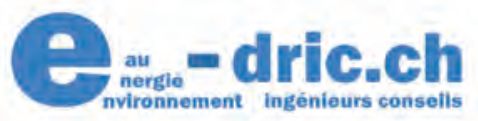




\section{River Flow 2014}

International Conference on Fluvial Hydraulics

The behaviour of river systems is a result of the complex interaction between flow, sediments, morphology and habitats. Furthermore, rivers are often used as a source of water supply and energy production as well as a waterway for transportation. The main challenge faced by river engineers today, in collaboration with environmental and ecological scientists, is to restore the channelized rivers under the constraints of high urbanization and limited space, as well as sustainable water use.

During the seventh International Conference on Fluvial Hydraulics "River Flow 2014" at École Polytechnique Fédérale de Lausanne (EPFL), Switzerland, scientists and professionals from all over the world addressed this challenge and exchanged their knowledge regarding fluvial hydraulics and river morphology. This book comprises the proceedings of the high quality contributions of the participants, which reflect the state-of-the-art in the fields of river hydrodynamics, morphodynamics, sediment transport, river engineering and restoration. The conference was organized under the auspices of the Committee on Fluvial Hydraulics of the International Association for Hydro-Environment Engineering and Research (IAHR). Past River Flow conferences have witnessed a significant increase in participation of our community of river engineers and researchers, confirming the need for such a forum.

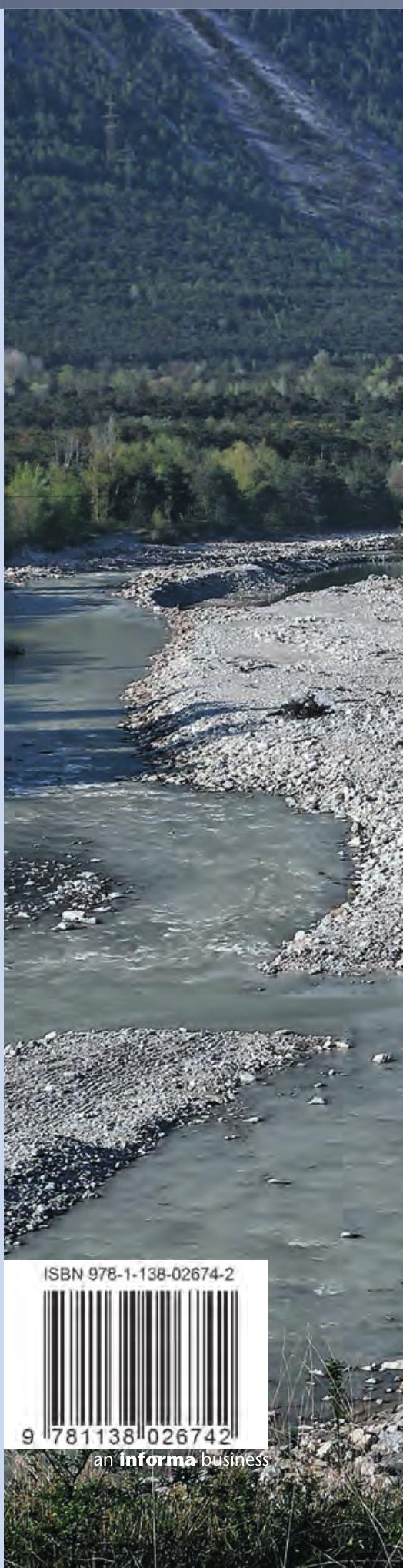

